\title{
Small photovoltaic setup for the air conditioning system
}

\author{
Maciej Masiukiewicz, ${ }^{1, *}$ \\ ${ }^{1}$ Opole University of Technology, Department of Mechanical Engineering, 5 Mikołajczyka st., 45-758 Opole, Poland
}

\begin{abstract}
The increasing interest in air conditioning systems for residential applications in Poland will certainly increase the demand for electricity during the summer period. Due to this fact a growing interest in solutions that help to lower the electricity consumption in this sector is observed. The problem of increased energy demand for air conditioning purposes can be solved by transfer the consumption of electricity from the grid system to renewable energy sources (RES). The greatest demand for cooling occurs during the biggest sunlight. This is the basis for the analysis of technical power system based on photovoltaic cells (PV) to power the split type air conditioner. The object of the study was the commercial residential airconditioning inverter units with a capacity of $2.5 \mathrm{~kW}$. A network electricity production system for their own use with the possibility of buffering energy in batteries (OFF-GRID system). Currently, on the Polish market, there are no developed complete solutions dedicated to air conditioning systems based on PV. In Poland, solar energy is mainly used for heat production in solar collectors. The proposed solution will help to increase the popularity of PV systems in the Polish market as an alternative to other RES. The basic conclusion is that the amount of PV energy generated was sufficient to cover the daily energy requirement of the air conditioner.
\end{abstract}

\section{Introduction}

The IPCC's Fifth Assessment Report-AR5 confirms unequivocally global warming and provides evidence of its substantial and wide-ranging consequences. The increase in average temperature and the prolonged periods of high temperatures are responsible for permafrost melting, heavy precipitations, floods, droughts, wildfires are some of the most significant effects caused by climate change that are likely to increase over time and can deeply affect both environment and society [1].

The study of urban energy consumption is becoming more and more important because of three main facts:

First - urban population is increasing: in 1950, $30 \%$ of the world population lived in cities, and 54\% in 2014, and this ratio will reach $66 \%$ in 2050 , that being around 6.5 billion of persons, i.e. 2.6 billion persons more than nowadays. Therefore, urban development is a crucial issue, in particular from an energy point of view as urban energy consumption per capita is also increasing $(+32 \%$ in the last 40 years).

Second - the energy paradigm changes: the need of dramatically reducing greenhouse gas emissions as well as fossil energy issues favor the use of renewable energies, which are often decentralized and intermittent. Related polices, currently ongoing in many countries worldwide, change the previous centralized energy management scheme, which requires a better understanding and forecasting of power demand and power production, in particular in cities, where the network in dense.

Third - urban heat stress during hot seasons due to the urban heat island (UHI) effect may further intensify effects of probable more frequent heat waves in the context of climate change. This can lead to dramatic public health problems as well as energy issues due to the multiplication of active cooling devices, which would also contribute to increase urban air temperatures.

Therefore, urban energy consumption have been a critical research problem for the last 30 years (referenced 219 papers concerning only urban energy models [2]), and will certainly still remains a major issue for the following years [3].

Summer air conditioning represents a growing market in buildings worldwide, with a particularly significant growth rate observed in European commercial and residential buildings [4]. Increasing interest in residential air conditioning systems in Poland results in a simultaneous increase in demand for electricity in the summer [5]. Due to this fact, there is a growing interest in solutions that reduce the energy consumption in this sector. This problem can be solved, among others by transferring the power consumption of air conditioning systems from system sources to renewable energy sources (RES) [6].

There are no comprehensive solutions, currently available in the Polish market, dedicated to air conditioning systems based on photovoltaic cells (PV). In Poland, solar energy is mainly used for the production

* Corresponding author: m.masiukiewicz@po.opole.pl 
of heat in the solar collectors.

The use of a PV system to power air conditioning seems to be an intuitive solution. Air conditioning works most often in the summer when the sun is abundant, and photovoltaic panels provide the most electricity.

\section{Problem definition}

The most important problem in the design of autonomous PV systems is the selection of the power source. PV generators and battery module packs adjusted to the level of electrical power demand [7].

Calculating the required volume of PV modules to power a split air conditioner requires the daily electricity consumption estimating. The conducted analysis concerns only the summer period, where there is a need for cooling. Due to the use in the inverter air conditioner rotary compressor, consumption is variable and depends on the heat load of the air-conditioned room. The heat load depends on the number of the operating and type of the devices, the number of residential people, and the outside temperature whether condition.

The most common device in Poland is a system with a cooling capacity of $2.5 \mathrm{~kW}$, which roughly translates into approx. $0.85 \mathrm{~kW}$ of electrical power demand. Due to the high cost of the PV system, we are looking for the optimum area for the modules and the size of the necessary battery capacity that will provide the power for a typical split air conditioner depending on: local sunlight, PV conversion efficiency, outdoor air temperature. These affects the amount of heat load of the residence,

When analyzing, consider periods in which the PV cells do not work (night, overcast) but there is a need for cooling. Therefore there is a need for the optimum capacity of energy battery bank adjustment to provide power during solar shortage periods to ensure uninterrupted operation of the system.

\section{Measurement setup and method}

The study was conducted on an autonomous system that is preferred from the seasonal power supply point of view and integrates the PV SMART-GRID system into the air conditioning system [8].

The Toshiba AvAnt residential SPLIT air conditioner inverter (RAS-107SAV-E6 outdoor unit, RAS-107SKV-E6 indoor unit) has the following characteristics: Cooling capacity $-2.5 \mathrm{~kW}$; Cooling range (min - max) $-1.2 \div 3.0 \mathrm{~kW}$; Power consumption (min./nominal/max.) - 0.29/0.77/1.05kW; EER - 3.25; SEER - 5.1; Energy efficiency class - A [9].

Voltcraft Energy Logger 4000 Energy Meter was used to collect instantaneous power consumption data from the air conditioner unit [10].

Analysis in real condition operation of the PV system was carried out on a research facility located on the building of the Faculty of Mechanical Engineering of the Opole University of Technology (OUT). The obtained data characterize the operation of PV cells for the Opole City region in Poland. PV installation consists of the following components: 1 - Six ETP660240WW $\mathrm{PV}$ modules with a power rating of $240 \mathrm{~W}_{\mathrm{p}} ; 2$ - Sunny Island 2224 Inverter with 2200W AC power; 3 - Sunny Boy 1300TL-10 Network Inverter with 1400W DC; 4 Sunny Home Manager; 5 - Sunny Remote Control; 5 Battery protection Batfuse B.0100; 6 - Four 240Ah Victron AGM 6V batteries connected to give total voltage of 24V; $7-500 \mathrm{~W}$ VAWT charge controller; 8 Sunny WebBox.

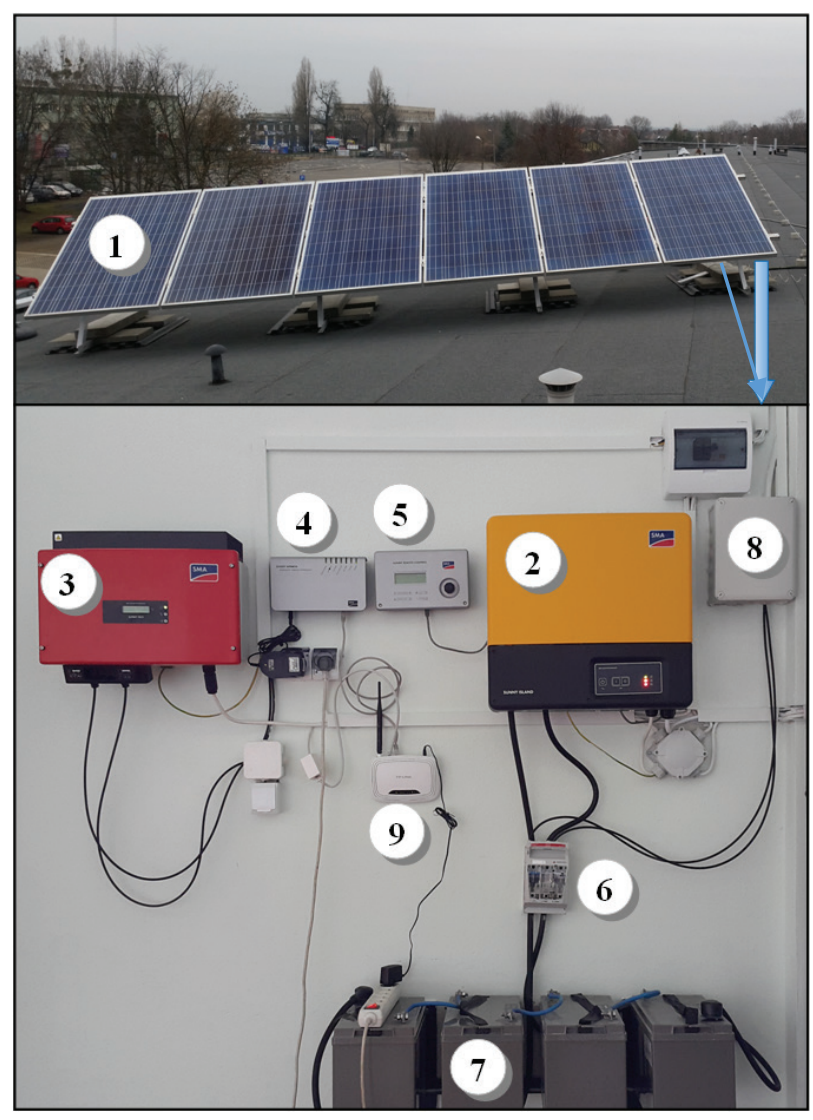

Fig. 1. PV measurement setup overview in the Department of Mechanical Engineering (Opole University of Technology).

The basic component of the PV installation are 6 polycrystalline photovoltaic modules (ET Solar ETP660240WW) serial connected with a total peak power of $1.44 \mathrm{kWp}$, a single module efficiency of $14.75 \%$ and a total cell surface area of $8.761 \mathrm{~m}^{2}$ are shown in Fig. 1.

Installation archives min. electricity generation on a given day. The example of the electricity generated for the day of 2 June 2017 is shown in Fig. 2.

To present the operation of the air conditioning system supplied by the PV system, data were presented: global irradiance total solar radiation intensity for City of Opole, power output from the PV system, power consumption of the air conditioner, and outdoor air temperature.

The meteorological station of the Faculty of Mechanical Engineering of the OUT, whose geographical location is $\mathrm{N} 50^{\circ} 41.027^{\prime} \mathrm{E} 17^{\circ} 56.620^{\prime}$, was used to record the intensity of solar radiation and outside air temperature. Data is averaged and saved with an interval of 900 s. 


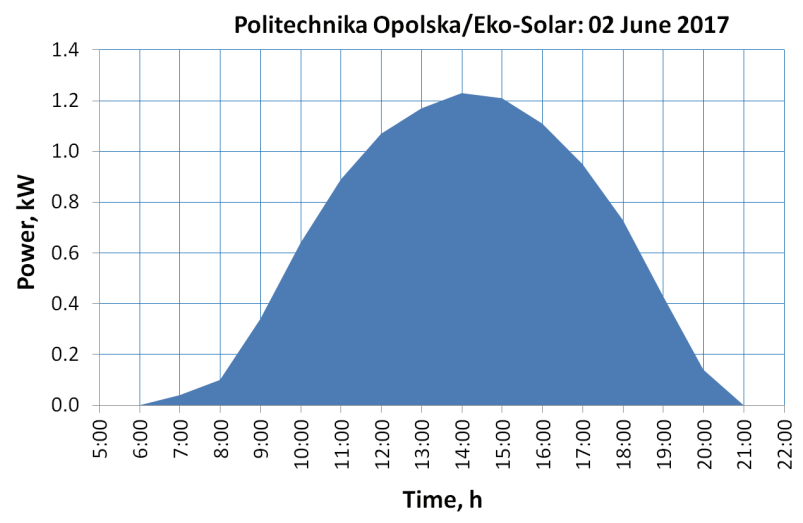

Fig. 2. Electricity generated for the day of 2 June 2017 [11].

Collection of data from PV inverters and their transmission to the server is provided by Sunny Webbox. The parameters of the PV system are constantly being saved since it is started, and access: to them is via a web page (Tab. 1.).

Data is averaged and recorded at an interval of 3600s.

Table 1. Overview of the daily report obtained from the Sunny Portal system for day of June 2, 2017 [11].

\begin{tabular}{|c|c|c|}
\hline $\begin{array}{c}\text { Daily Output } \\
{[\mathrm{kWh}]} \\
6 / 2 / 2017\end{array}$ & $\begin{array}{c}\text { Monthly Output } \\
{[\mathrm{kWh}]}\end{array}$ & $\begin{array}{c}\text { Yearly Output } \\
{[\mathrm{kWh}]} \\
\text { June } 2017\end{array}$ \\
\hline 10.15 & 221.97 & 595.38 \\
\hline
\end{tabular}

The information about the instantaneous power consumption of the air conditioner was obtained using the Voltcraft Energy Logger 4000 energy meter. The data is written to the internal memory at interval $60 \mathrm{~s}$ from where it can be transferred to the SD memory card.

A summary of all collected data allows to specify: First - the solar radiation with PV power output - PV system real capacity. The photovoltaic conversion efficiency was calculated from equation (1):

$$
\eta=\frac{P}{E \cdot A} \cdot 100 \%
$$

where: A - cell surface PV, $\mathrm{m}^{2}$; E - global radiation, $\mathrm{W} / \mathrm{m}^{2} ; \mathrm{P}$ - power, $\mathrm{W}$

Second - generated power of PV installation with instantaneous power requirement by air conditioner of the actual coverage of air conditioner needs by PV system. And third - momentary power demand by air conditioner with outside temperature with the influence of outside air temperature on the heat load.

An exemplary graph of the characteristics described in the example on the day of June 6, 2017 for the city of Opole is shown in Fig. 3.

The sunshine data for the city of Opole from 2016 and 2017 were also collected to determine the availability of solar energy for PV panels in the analyzed period (Tab. 2). This data is helpful for estimating the size of batteries to compensate temporary power shortages in the PV plant.

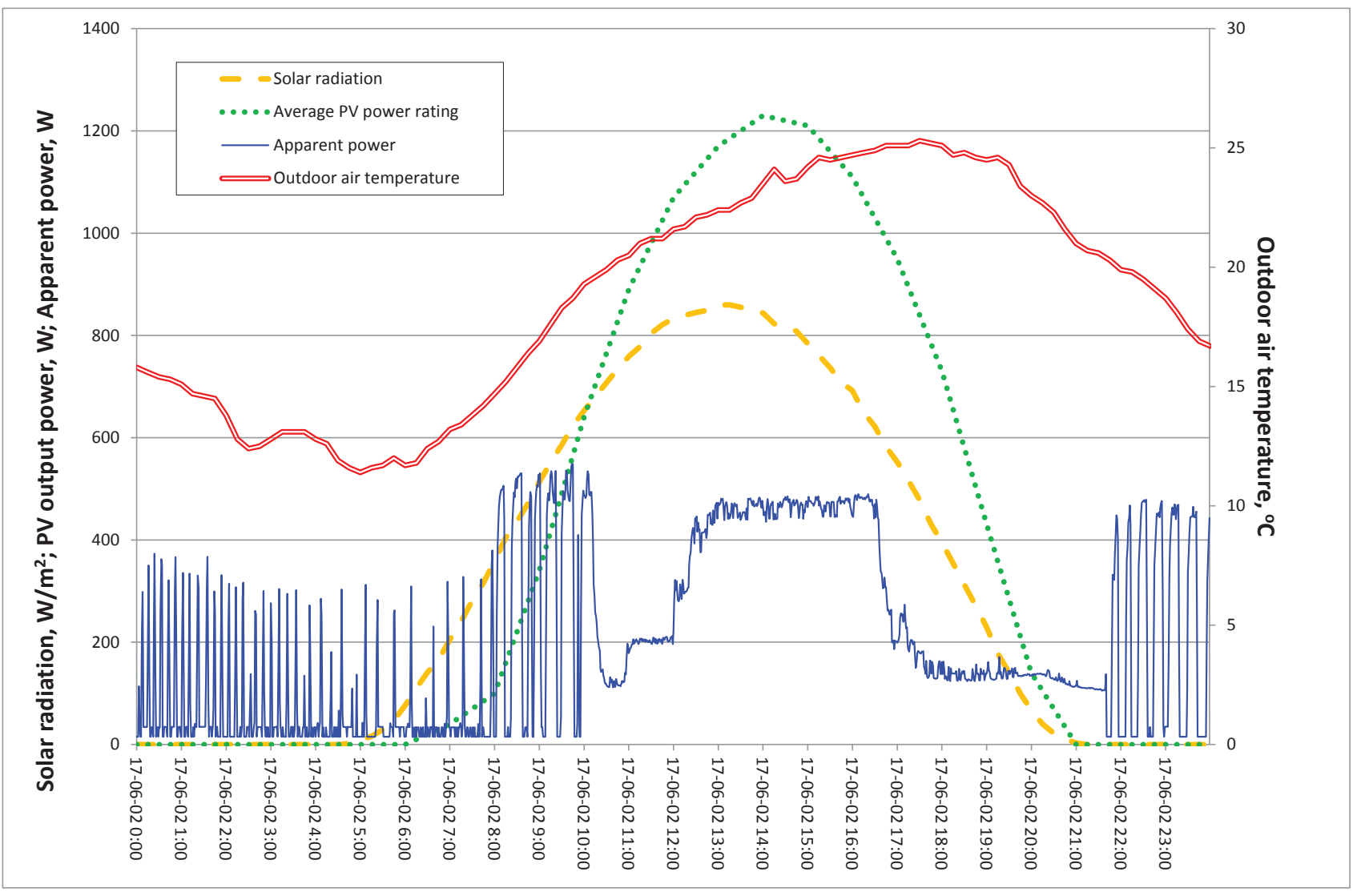

Fig. 3. Set of recorded parameters of the total measurement system for one day. 
Table 2. Average sunshine hours in the city of Opole [12].

\begin{tabular}{|l|c|c|c|c|c|}
\hline \multicolumn{2}{|c|}{} & \multicolumn{2}{|c|}{$\mathbf{2 0 1 6}$} & \multicolumn{2}{c|}{$\mathbf{2 0 1 7}$} \\
\cline { 3 - 6 } & May & June & May & June \\
\hline Accumulated Sunshine Hours & h & 248.3 & 273.3 & 212.8 & 291.3 \\
\hline
\end{tabular}

\section{Results and disussion}

The study was held for 13 days, from 25.06.2017 to 06.06.2017r. On the June 7th the fault was covered by the air conditioner and switched off the cooling function. During that period, there was a demand for active power in the range of $6.7 \div 741.4 \mathrm{~W}$; Apparent power in the range of $13.7 \div 938.5 \mathrm{~W}$. The air conditioner in this period consumed $65.7 \mathrm{kWh}$ of energy and the daily energy demand varied between 0.74 and $11.905 \mathrm{kWh}$.
During the same period, the PV installation achieved average photovoltaic conversion efficiency at $7.52 \%$, peak at $19.16 \%$, and generated $102.6 \mathrm{kWh}$ of electric energy. The highest achieved power was $1.27 \mathrm{kWp}$ (nominal electrical power of the system is $1.44 \mathrm{kWp})$. The electrical power and efficiency of the PV system from the background of the solar radiation view is shown in Fig. 4. In the analyzed period, the outdoor air temperature variations ranged from $10.5^{\circ} \mathrm{C}$ to $32.2^{\circ} \mathrm{C}$. All of the described characteristics are shown in Fig. 5.

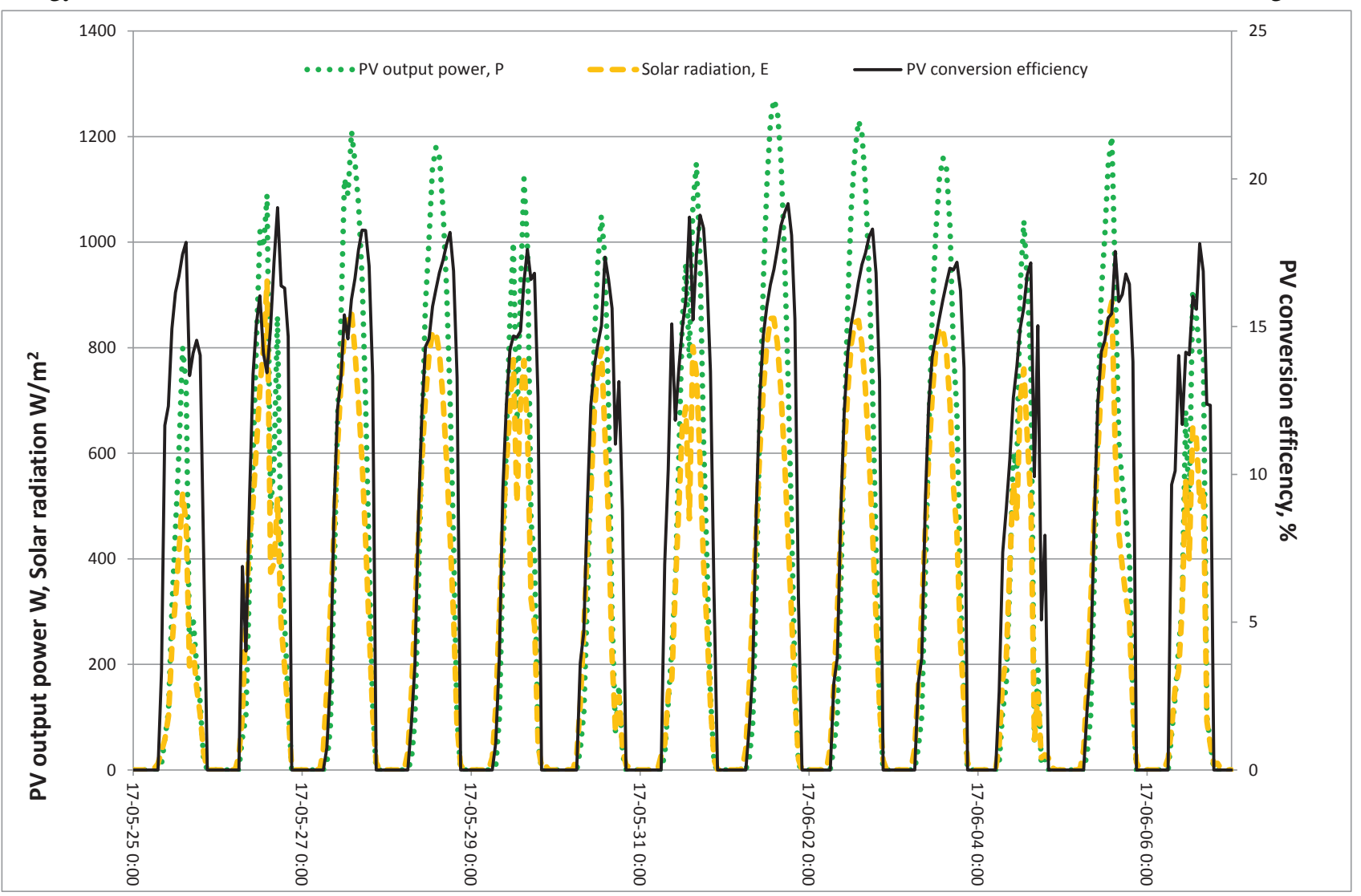

Fig. 4. Achieved electrical power and efficiency of the PV system for the analyzed period with the referenced solar irradiation.

The main task of the battery bank is the compensation of the electricity shortage supplied from the main PV source. Power shortage as well as power bank capacity depends on the day time, the radiation intensity variation and the need of energy reservation level. It is recommended to reserve the energy for 2-3 days in summer and 3-5 days in winter. In addition, in order to extend the life of the batteries, it is recommended that $50 \%$ to $100 \%$ of the power supply be used for their selection [13]. Based on the data collected, the average sunshine hours (Table 2.) and the needed for the air conditioner's undisturbed operation, the battery bank capacity was estimated. The energy reserve factor is shown in Table 3. The $F$ factor was calculated by assuming the summer conditions of a minimum 2 days reserve, extending it by the number of hours without sunshine [12]. 


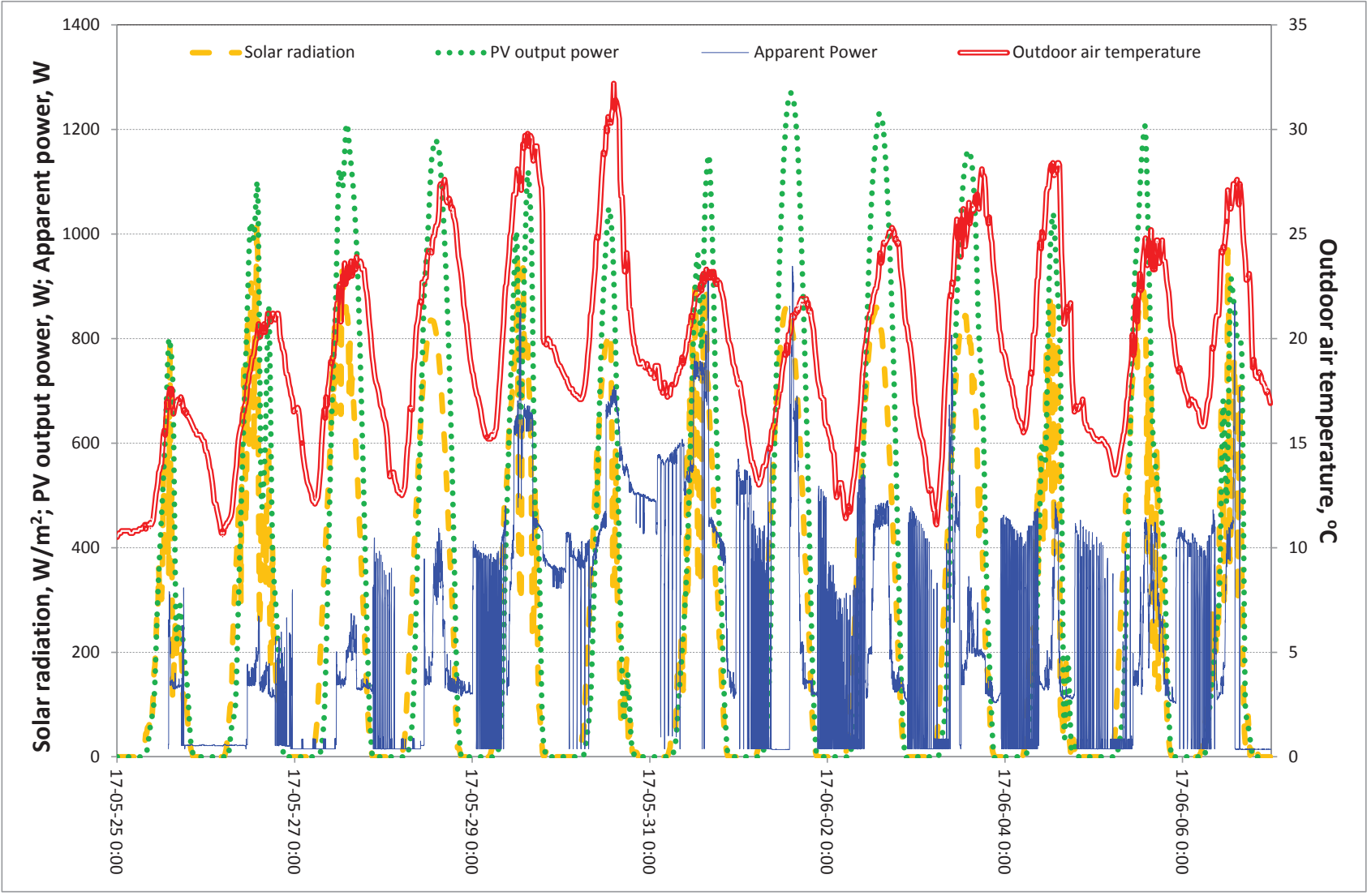

Fig. 5. The recorded parameters of the total measurement system for the analyzed period.

Table 3. Estimated $F$ factor values associated with the energy reserve.

\begin{tabular}{|c|c|c|}
\hline Year & $\mathbf{2 0 1 6}$ & $\mathbf{2 0 1 7}$ \\
\hline May & 3 & 2 \\
\hline June & 2.7 & 2.5 \\
\hline Average & \multicolumn{2}{|c|}{2.55} \\
\hline
\end{tabular}

Battery capacity was calculated from equation (2):

$$
C=\frac{2 \cdot W \cdot F}{U}, A h
$$

where: $\mathrm{F}$ - factor related to energy reserve, -; W - daily energy demand, Wh; U - battery voltage, $\mathrm{V}$

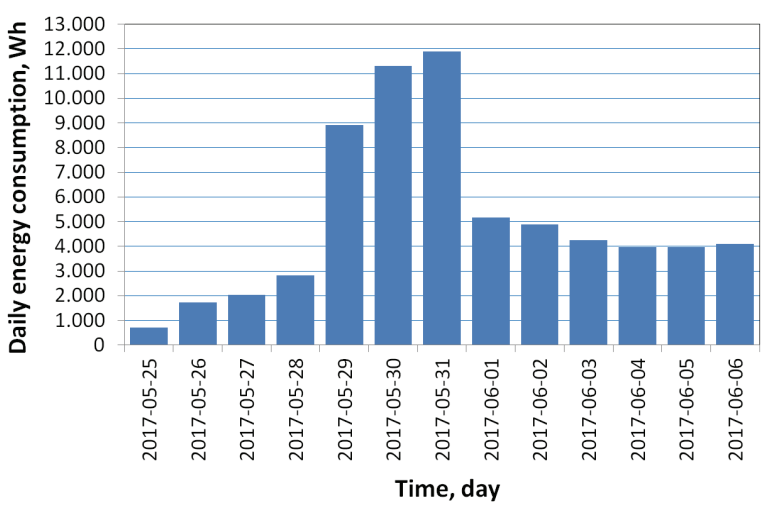

Fig. 6. Measured daily energy consumption of the Split Air Conditioning System.
The highest measured daily energy consumption was $11.9 \mathrm{kWh}$ is shown in Fig. 6. The required battery capacity (at $24 \mathrm{~V}$ ) was calculated according equation (2) at 2529.8Ah.

\section{Conclusions}

The power consumption of an air conditioner analysis, shows four characteristic modes of operation standby mode, disturbed standby mode, work mode and disturbed work mode. During standby mode, the device exhibited a constant power requirement of about $14.0 \div$ $21.5 \mathrm{~W}$. The disturbed standby mode time is characterized by short time power demands of over $50 \mathrm{~W}$. During proper operation in the work mode, the device has a power requirement of over $50 \mathrm{~W}$, and the power fluctuation is fairly smooth. One of the basic conclusions, which is a promising expectation, from a commercial point of view is that the highest peaks in power demand were at maximum PV output. On the warmest days, there were periods of disturbed work mode characterized by short power drops to the standby level.

On a daily basis, there is no homogeneous configuration of four operation modes. However, there are some analogies between the following days. After a period of work mode, per day, there is a period of disturbance in the nighttime. In the warmest days (e.g. 29.05.2017-01.06.2017) instead of disturbed standby 
mode, work is disturbed. These effects can be caused by the building's temperature inertia, the impact of adjacent rooms, the influx of ventilation air and the household equipment operation.

Next basic conclusion is that the amount of PV energy generated was sufficient to cover the daily energy requirement of the air conditioner. However energy shortage occurred during the nighttime when the device continued to operate in the disturbed standby mode and disturbed work mode. This means that during the night, either the use batteries is necessary or give up air conditioning at all. But then there will be need to invest more energy in removing the accumulated heat the next day. However, this case will result in worse thermal comfort in the morning.

\section{References}

1. F.F. Pietrapertosa, Renew. Sust. Energ. Rev. (2017), (to be published)

2. J. Keirstead, M. Jennings, A. Sivakumar, Renew. Sust. Energ. Rev. 16, 6 (2012).

3. L. Frayssinet, Renew. Sust. Energ. Rev. (2017), (to be published)

4. C. A. Balaras, G. Grossman, H. M. Henning, C. A. I. Ferreira, E. Podesser, L. Wang, E. Wiemken, Renew. Sust. Energ. Rev. 11, 2 (2007).

5. Air Conditioning and Ventilation Market in Poland and Silesian Voivodeship (2013) (in Polish) http://pnt.euro-

centrum.com.pl/files/post/830/Rynek-Klimatyzacjii-Wentylacji-w-Polsce-i-wojewodztwie-slaskim.pdf [access: 12.07.2017]

6. D. Kwiecień, Forum Wentylacja, Salon Klimatyzacja (Warsaw, 2009) (in Polish)

7. E. Klugmann-Radziemska, Renewable energy sources, computational examples (WPG, Gdańsk 2013) (in Polish)

8. S. Anweiler, W. Fedak, R. Ulbrich, B. Jarosz, Instal 7-8 (2016)

9. TOSHIBA catalogues: http://www.toshibahvac.pl/pliki/toshiba_katalog_2015.pdf [access: 12.07.2017]

10. Voltcraft catalogues: http://www.voltcraft.pl/ (access: 15.07.2017)

11. Sunny Portal www.sunnyportal.com (access: 17.07.2017)

12. Wether reports (in Polish) http://www.weatheronline.pl (access: 14.07.2017)

13. D. Żabicki, Batteries for photovoltaic installations (in Polish) http://www.fachowyelektryk.pl/technologie/odnaw ialne-zrodla-energii/1648-akumulatory-doinstalacji-fotowoltaicznych.html 